\title{
41. NEOGENE PALEOBATHYMETRY OF THE MEDITERRANEAN BASED ON BENTHIC FORAMINIFERS FROM DSDP LEG 42A
}

\author{
Ramil Wright, Beloit College, Beloit Wisconsin ${ }^{1}$
}

\begin{abstract}
Quantitative and qualitative bathymetric analysis of Neogene benthic foraminiferal faunas from eight drill sites in the Mediterranean Sea confirms the presence of deep basins immediately after the deposition of the evaporites of the Messinian. Analysis of the faunas of two sites which penetrated the evaporitic sequence establishes the existence of deep basins in both the eastern and western Mediterranean prior to the Messinian. Although the recovery of samples near the upper and lower boundaries of the evaporites was not continuous there is no evidence of the presence of faunas which are transitional between the deep water assemblages and the shallow water Messinian faunas. These observations all lend considerable support to a deep basin desiccation model for the formation of the evaporites.
\end{abstract}

\section{INTRODUCTION}

Reconstruction of the Neogene paleobathymetry of the Mediterranean area has been based primarily on outcrop studies of structural basins which have been uplifted around the margins of the Mediterranean, on cores taken along the margin, and on geophysical studies of the central deep basins. The first deep basin cores were taken during DSDP Leg 13 and yielded preliminary conclusions based on a qualitative examination of the benthic foraminifers by W. Maync (Ryan, Hsü, et al., 1973) and occasional ostracode carapaces (Benson, 1973).

This study is based on the benthic foraminifers collected from the Leg 42A sites (Figure 1) and examined qualitatively and quantitatively to provide estimates of water depth during the Neogene.

\section{BATHYMETRIC ZONATION}

The utilization of benthic foraminifers as bathymetric indicators is dependent on comparisons between the Neogene fauna and occurrences of the same and related species in the modern Mediterranean and adjacent waters. The modern Mediterranean is not a typical ocean basin. The restriction to oceanic circulation caused by the 320 -meter deep sill at Gibralter has created a water mass structure whose deep bottom temperatures $\left(13^{\circ} \mathrm{C}\right)$ are warmer than those of water of similar depth in the rest of the ocean basins of the world. Consequently, the resulting vertical zonation of benthic foraminifers in the Mediterranean differs from that of the adjacent Atlantic at depths greater than 1300 meters. Qualitative studies of the Recent bathyal benthic foraminiferal fauna in the Mediterranean

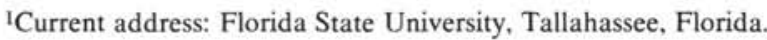

(Blanc-Vernet, 1969; Colom, 1974; Parker, 1958; Todd, 1958) indicate that many elements of the modern Atlantic deep-sea benthic foraminiferal fauna (Phleger et al., 1953) are missing from the Mediterranean today. Living benthic foraminiferal faunas in the Mediterranean today display changes in species composition to depths of 1000-1300 meters. Below these depths there is little change in the species composition of the faunal assemblages. However, a quantitative study of the Recent Mediterranean fauna (Cita and Zocchi, in press) revealed that deeper zones could be identified on the basis of whole fauna abundance, the number of individuals per species and the number of species.

As a consequence of these differences between the Mediterranean fauna and those of "normal" ocean basins, the bathymetric zonation scheme of the open ocean (Hedgepth, 1957) used in previous DSDP studies (Ingle, 1973) is unsuitable for work in the Mediterranean. A bathymetric zonation (Table 1) has been specifically designed for the Mediterranean and is based on the distribution of the benthic foraminifers and on the hyposgraphic curve of the Mediterranean.

\section{BENTHIC FORAMINIFERS AS BATHYMETRIC INDICATORS}

Benthic foraminifers are sensitive to a variety of environmental factors. It is not clear whether or not they respond to depth per se or only to depth-related factors such as temperature, salinity, light intensity, nutrient distribution, and oxygen concentration. However, it is clear that some species have coincident and well-defined upper depth limits in various ocean basins. Bandy and Chierici (1966) recognized several such "isobathyal" species in the Mediterranean. More weight was given to these species when paleobathymetric interpretations were made from the Mediterranean cores. 


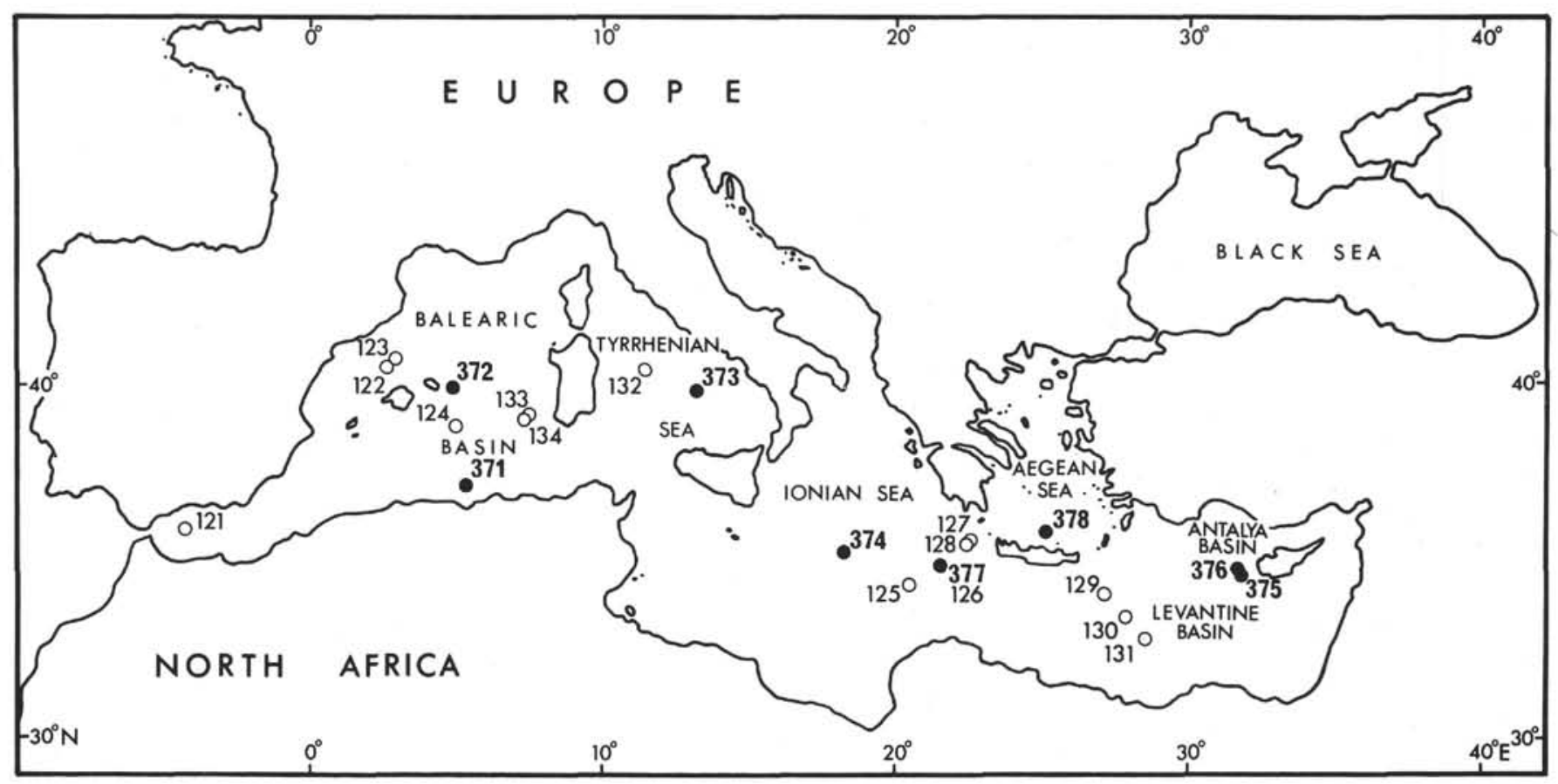

Figure 1. Location of drill sites, DSDP Leg 42A (in relation to those of Leg 13).

TABLE 1

Bathymetric Zonation, Mediterranean Sea

\begin{tabular}{lcc}
\hline \multicolumn{1}{c}{ Zone } & Upper Limit $(\mathrm{m})$ & Lower Limit $(\mathrm{m})$ \\
\hline Inner neritic & 0 & 50 \\
Outer neritic & 50 & $150-200$ \\
Upper epibathyal & $150-200$ & $500-700$ \\
Lower epibathyal & $500-700$ & $1000-1300$ \\
Upper mesobathyal & $1000-1300$ & 1800 \\
Mid mesobathyal & 1800 & 2500 \\
Lower mesobathyal & 2500 & 4000 \\
Infrabathyal & 4000 & \\
\hline
\end{tabular}

Whenever possible, the paleobathymetric interpretations of this study were made by analogy with the fauna of the Mediterranean today. However, a number of species were encountered in the cores which are not living in the modern Mediterranean, but are living in other seas and oceans of the world. Where these particular species occur in areas whose benthic foraminifers are well studied such as the Gulf of Gascogne (Caralp et al., 1970; Pujos-Lamy, 1973), the Gulf of Mexico (Parker, 1954; Phleger and Parker, 1951), the Gulf of California (Bandy, 1961), the Pacific Ocean (Bandy and Arnal, 1957; Cushman, 1933, 1942; Todd, 1965; Uchio, 1960), and the Andaman Sea (Frerichs, 1970 ), their recorded depth distribution was utilized. Those species whose depth distribution in several of these areas was consistent were given more weight in the interpretations than rare species or those whose depth ranges display great variation.

Because foraminiferal tests may be transported downslope, it was necessary to eliminate from consideration any obviously reworked specimens. Such specimens were recognized in various ways. The presence of unlikely assemblages such as the occurrence together of
Ammonia spp. and Elphidium spp. with bathyal species of Cibicidoides and Bulimina indicate downslope transport of the first two genera. Another indication of displacement is the presence of worn and abraded species mixed with well-preserved specimens of other species. Not all displaced specimens are abraded nor are they always obviously out of place. Consequently, the enclosing sediment was examined for signs of grading, size sorting, and abundant detrital material which might indicate downslope transport. Because modern faunas may also be displaced downslope, heavy reliance was placed on the upper depth limits of Recent species when drawing analogies for paleodepth determinations. The modern downslope transport of tests may be unrecognized today and consequently the recorded lower depth limits of some species may be considerably greater than is actually the case; hence upper depth limits are of special significance.

Those species representing the deepest habitat in a fossil assemblage were assumed to be in place and those species indicative of shallower depths were considered as possible downslope contiminants. Consequently, the paleobathymetric interpretations based on the deepest dwelling assemblages represent a minimum estimate of the paleodepth.

However, some modification of this minimum estimate can be made if one considers the abundances of selected species and also if one evaluates the morphology of selected species.

Many Recent benthic foraminifers exhibit a vertical quantitative distribution which approximates a Gaussian curve (Theyer, 1971). Consequently, the abundance of a species in an assemblage may give clues to depth and should be considered. Rare occurrences of a common species probably indicate that it lies near its 
upper or lower depth limit whereas abundant specimens of a common species may be indicative of a paleodepth well below the upper and well above the lower depth limits. As an example, consider three common Mediterranean species (Bandy and Cherici, 1966): Hoeglundina elegans has its upper depth limit at about 100-150 meters and increases in abundance to $700 \mathrm{~m}$; Gyroidina altiformis has its upper depth limit at 200 meters, is abundant below 600 meters, and very abundant below 800 meters; Cibicides wuellerstor $f$ is found rarely as shallow as 500 meters and is most common below 1000-1200 meters.

A sample containing abundant specimens of $H$. elegans, rare specimens of $G$. altiformis, and no specimens of $C$. wuellerstorfi, would be evaluated as lying between 200-500 meters and probably closer to 200 meters in depth. A sample containing abundant $H$. elegans and G. altiformis but no $C$. wuellerstorfi would be evaluated as representing a depth of about 500 meters. Although the deepest dwelling species in the assemblage, $G$. altiformis, has an upper limit of 200 meters, the deeper estimate of 500 meters would be assigned on the basis of the abundances. This utilization of abundance is used with care as downslope transport can mask actual abundances and give a depth estimate that is too shallow. Only the common species can be utilized in the manner.

Some genera and species exhibit morphological variation with depth and recognition of these ecophenotypic specimens may give some clues to the water depth. A survey of the literature on depth-related morphological changes in selected genera (Boltovskoy and Wright, 1976, p. 242) shows that species of Pullenia become more spherical with depth, Cibicides becomes more oblate and exhibits more prominent sutures, the species of Eponides tend to become smaller, Gyroidina becomes larger, Bolivina develops sinuate sutures, ornamentation on specimens of Trifarina becomes less pronounced, and hispid Uvigerina become dominant over costate forms. These phenomena were all used in the evaluation of paleodepths. Depth-related morphological changes in selected species are discussed below.

The ratio of planktonic foraminiferal tests to benthic ones was also used to give an indication of paleodepth. Grimsdale and Morkhoven (1955) first clearly documented the increasing proportion of planktonic versus benthic tests in deeper water; numerous studies have confirmed these observations and the planktonic-benthic ratio has been used successfully in many studies of fossil sediments to help in estimating depth of deposition.

An evaluation of data from more than 500 samples from the Mediterranean, Red Sea, Arabian Sea, and the Gulf of Mexico shows the following general trends.

\begin{tabular}{cc}
\hline Percent planktonic & Average depth $(\mathrm{m})$ \\
\hline 10 & 65 \\
25 & 120 \\
50 & 300 \\
75 & 890 \\
90 & 1400 \\
\hline
\end{tabular}

The data have not yet been analyzed statistically, but a visual examination indicates that depth estimates based on these averages may vary by as much as $50 \%$. Thus, the planktonic-benthic ratio gives only a crude estimate of paleobathymetry; it is most useful when used in conjunction with other criteria.

A variety of benthic species occurring in the Leg $42 \mathrm{~A}$ sites were used in this investigation to estimate paleobathymetry. Only those species about which there is little taxonomic debate or confusion were used. Significant species are listed below with a brief discussion of their bathymetric distribution in various oceanic bodies as well as any morphological features which give clues about water depth.

\section{Inner Neritic Assemblage}

Ammonia beccarii-

Asterigerinata mamilla-This species has its shallowest occurrence in the inner neritic zone and is common in the outer neritic zone in Mediterranean waters.

Bolivina spp.-Most of the numerous species of Bolivina present in the core samples (see Wright, this volume) have wide bathymetric ranges with their initial appearances in the inner and outer neritic zones. They persist as common forms into the upper mesobathyal zone. Exceptions to this general observation are noted below.

Discorbis spp.-The several species of Discorbis found in the Leg $42 \mathrm{~A}$ cores (see Wright, this volume) are all typical of the inner neritic zone.

Elphidium spp.-The numerous species of Elphidium recorded in the Mediterranean cores are all indicative of the inner neritic environment.

Neoconorbina terquemi-

Nonionella opima-This species is abundant between 40-100 meters in the Mediterranean today.

Pullenia salisburyi-This species has its first appearance at 18-37 meters in the Gulf of California and at 175 meters in the Gulf of Gascogne.

\section{Outer Neritic Assemblage}

\section{Bigenerina nodosaria-}

Cassidulina spp.-The several species of Cassidulina encountered in the core samples (see Wright, this volume) are representative of all depths from the outer neritic zone downward.

Gavelinopsis praegeri-

Gyroidina umbonata-This species occurs at all depths below 100-150 meters in the Mediterranean today.

Hanzawaia boueana-This species is common in outer neritic environments in the modern Mediterranean and is a frequent element in displaced faunas.

Hoeglundina elegans-This species has its shallowest occurrence at 150 meters in the Mediterranean and is most frequent at 700 meters.

Pseudoclavulina crustata-

Trifarina angulosa angulosa-The robust strongly costate form of this species is common in the outer neritic and upper epibathyal zones in the Mediterranean and Gulf of Gascogne. 
Valvulineria complanata-This species and its isomorph $V$. bradyana are abundant between 40-110 meters in the Mediterranean today.

\section{Upper Epibathyal Assemblage}

Bolivina albatrossi, B. dilitata-The bolivinids with sinuate sutures have their common occurrences below 200 meters.

Cibicides pachyderma-Under the names of $C$. aff. floriadanus and $C$. pseudoungerianus, this species has been described in waters of all depths but is not abundant on the shelf in the Mediterranean today.

Epistominella exigua-Although this species makes its first appearance in the outer neritic, it is common only from the upper epibathyal zone downward. Examination of specimens occurring from samples taken from many parts of the world at depths from the coastal zones to 3920 meters shows a particular morphological change occurring with depth which is useful in estimating paleobathymetry. The majority of specimens living above 450 meters have a rounded periphery and 6 to $6-1 / 2$ chambers per whorl whereas those in the deeper zones show an acute or subacute periphery and 5 to $5-1 / 2$ chambers per whorl.

Gyroidina altiformis-This species has its shallowest occurrences at 200 meters in the Mediterranean, becomes abundant below 600 meters, and very abundant below 800 meters.

Gyroidina soldanii-Variants of this species occur below 100 meters in the eastern Mediterranean and become persistent elements in the fauna below 300-400 meters. They occur below 400 meters in the Gulf of Naples.

Hyalinea balthica-This species has its shallowest occurrence at 100-175 meters in the Mediterranean, but becomes abundant only below 200 meters. The species reaches its greatest size between 165 and 470 meters and becomes considerably smaller with reduced ornamentation below 450 meters and down to its lower depth limit of 990 meters (Colom, 1970).

Karreriella bradyi-This species seems to have a wide range of upper depth limits ranging from about 150 meters in the Atlantic and Gulf of Mexico to 600 meters in the Gulf of Gascogne. It is never very abundant and this may account for the depth variation reported in the literature.

Lagenonodosaria scalaris-A detailed study of this species by Scorziello (1966) in the Gulf of Naples showed that it begins at about 100 meters and is abundant between 200 and 450 meters.

\section{Sigmoilina tenuis-}

Trifarina angulosa occidentalis-A smaller, more weakly ornamented form than the typical $T$. angulosa, this subspecies seems to occupy deeper water than $T$. angulosa angulosa.

Trifarina bradyi-Although not described from the Mediterranean today, this species makes its first common appearance at about 150 meters in the Gulf of Mexico and Gulf of Gascogne.

\section{Lower Epibathyal Assemblage}

Bulimina aculeata-Although its shallowest occurrence is in the upper part of the upper epibathyal zone, this species is quite common in the lower epibathyal zone.

Bulimina alazanensis-This species reaches its peak abundance between 500 and 1100 meters in both the Gulf of Mexico and the Andaman Sea. Its shallowest occurrence in the Gulf of Gascogne is 1400 meters where it is abundant between 2000 and 3200 meters.

Cibicides robertsonianus-This species occurs below 700 meters in the North Atlantic, below 800 meters in the Gulf of Gascogne, is most common below 1000 meters in the northeast Gulf of Mexico, and is usually found between 600 and 1100 meters in the northwest Gulf of Mexico.

Cibicidoides bradyi-Although this species is not well known in the Mediterranean today and may not exist there at all, it is present in the Pacific at depths greater than 700 meters and in the Andaman Sea below 350 meters.

Eggerella bradyi-This species is rarely reported from Recent Mediterranean waters, but is a fairly common species in the northeast Gulf of Mexico where it is most abundant deeper than 915 meters although it may occur as shallow as 150 meters. In the northwest Gulf of Mexico and the North Atlantic it occurs from 600 to 800 meters and downward. It is only abundant in the Gulf of Gascogne below 2500 meters.

Gyroidina orbicularis-This species is referred to as bathyal by Blanc-Vernet (1969) in the Mediterranean and reaches its greatest abundance between 500 and 1000 meters in the northeast Gulf of Mexico.

Nuttallides rugosus convexus-This species has its shallowest occurrence in the eastern Mediterranean at 541 meters.

Nuttallides umboniferus-Originally described from 4102 meters in the South Pacific, this species is common below 400 meters in the Gulf of Gascogne.

Oridorsalis umbonatus-This common species is able to live in the outer neritic environment and is found there in the Atlantic and northeast Gulf of Mexico but becomes a frequent component of the bottom populations at 1000 meters in the Andaman Sea, at 1200 meters in the Gulf of California, at 600 meters in the Pacific, and below 2000 meters in the Gulf of Gascogne.

Osangularia cultur-This species is not known in the Mediterranean today but is abundant below 400 to 600 meters in the Gulf of Mexico and below 970 meters in the Andaman Sea.

Pullenia bulloides-Although this species is reported as a rare element in the bathyal zones of the Mediterranean today, it occupies shallow water in the Gulf of Mexico and Andaman Sea and very deep water in the Gulf of California. It is used as a bathymetric indicator only with caution.

Pullenia quinqueloba-Although this species may occur rarely as shallow as 100 meters, it is only 
abundant below 500 meters in the northeast Gulf of Mexico, 940 meters in the northwest Gulf of Mexico, 800 meters in the Gulf of Gascogne, 1200 meters in the Andaman Sea, and 1700 meters in the Gulf of California.

Sigmoilopsis schlumbergeri-Although this species is found at 175 to 400 meters in the Mediterranean today, its most abundant occurrences are between 800 and 1200 meters. In the Gulf of Mexico it is usually found below 600 meters and below 1200 meters in the Gulf of Gascogne.

\section{Upper Mesobathyal Assemblage}

Articulina tubulosa-This species is referred to by Parker (1958) as a true deep-sea form. It occurs rarely as shallow as 700 meters in the eastern Mediterranean, but is only abundant below 2600 meters. In the western Mediterranean, it commonly occurs at depths greater than 1800 meters and rarely as shallow as 1300 meters.

Astrononion umbilicatulum-This species is not known from the modern Mediterranean, but occurs in mesobathyal depths in the Indian Ocean.

Bolivina pusilla-This species occurs only rarely in the outer shelf, and is abundant below 1000 to 1300 meters in the northeast Gulf of Mexico and the Andaman Sea.

Bulimina inflata-Although the taxonomy of the costate buliminids is confused, the Leg $42 \mathrm{~A}$ specimens are isomorphs of those which occur below 1500 meters in the Gulf of Gascogne and are most common in the mesobathyal zone.

Cibicides wuellerstorfi-This species occurs below 1000 meters in the Mediterranean today and at similar depths in most of the oceans of the world.

Cibicidoides kullenbergi-Not well known in the Mediterranean today, this species occurs in the North Atlantic deeper than 2100 meters and rare specimens are found as shallow as 580 meters in the northeast Gulf of Mexico although the species generally lies below 1000 meters there. In the Gulf of Gascogne its first appearance is at 1200 meters and it becomes abundant below 2100 meters.

Eponides polius-This species has its first occurrence at 200 meters in the Andaman Sea and at 585 meters in the Gulf of Mexico but becomes a persistent member of the faunal assemblage only at depths greater than 1000 meters in both of these areas. Its first abundant occurrence in the Gulf of Gascogne is at 2100 meters.

Eponides pusillus-This species, rare in the Mediterranean today, occurs there only at depths greater than 1000 meters. In the Andaman Sea it occurs at all depths and a morphologically similar form, E. turgidus, occurs from the outer neritic to mesobathyal depths in the Gulf of Mexico. If the modern Mediterranean is used as an analog, this species is indicative of upper mesobathyal depths, but it is somewhat suspect because of its occurrence elsewhere. It should not be used alone to estimate paleodepths.
Gyroidina delicata-Not common in the modern Mediterranean, this species is found in deep water Pleistocene cores in the eastern Mediterranean and a morphologically similar form identified as $G$. orbicularis by Caralp, et al. (1970) from the Gulf of Gascogne occurs deeper than 1200 meters.

Orthomorphina antillea-This species occurs at 1530 meters in the Andaman Sea.

Uvigerina hispida-This species dominates between 1500 and 1800 meters in the Gulf of California.

\section{Mid Mesobathyal Assemblage}

\section{Quinqueloculina venusta-}

In addition to the above species, the genus Melonis deserves mention. The reported occurrences and taxonomic confusion of the various robust Melonis (M. barleeanum, $M$. formosum, $M$. padanum, $M$. parkerae, $M$. pompilioides, and $M$. soldanii) make bathymetric discrimination difficult. The more compressed forms of this genus such as $M$. barleeanum have their shallowest occurrences in the outer neritic zone, but are most abundant below 200 to 600 meters, whereas the broader forms are restricted to the lower epibathyal zone and below.

\section{MEDITERRANEAN PALEOBATHYMETRY}

Site 371 (Figure 2) in the South Balearic Basin seems never to have been shallow since the early Pliocene. This area appears to have been at least as deep as 1200 to 1400 meters and perhaps deeper. The basin is 3000 meters deep today, but as these are minimum depth estimates there is no contradiction.

Site 372 (Figure 3) on the East Menorca Rise yielded the first pre-Messinian sediment samples in the deep Mediterranean. The faunal characteristics of the lower and middle Miocene sediments found there are not significantly different from those of the PlioPleistocene either in terms of species composition or in paleobathymetric interpretation (at least 1500 meters). The earliest Miocene sediment sampled at this site (Burdigalian) shows some evidence of having been deposited at somewhat shallower depths $(>900 \mathrm{~m})$; the state of preservation of the fauna is poor and paleobathymetric precision is not great. These sediments appear not to have been affected by any orogenic events. The details of the Messinian benthic foraminiferal faunas and their environmental interpretation are given in Cita et al. (this volume).

Site 373A, in the Tyrrhenian Basin, yielded only two cores with benthic foraminifers before penetrating volcanic rocks and volcanically altered sediment. The Plio-Pleistocene benthic foraminiferal faunas are indicative of a mesobathyal habitat.

The Plio-Pleistocene history of Site 374 in the Messina Abyssal Plain seems to be that of a persistent, but not necessarily stable, basin whose depth has remained in the upper mesobathyal zone since at least the early Pliocene (Figure 4). The early Pliocene fauna just above the Messinian evaporites is indicative of slightly shallower depths, but is still in the upper 


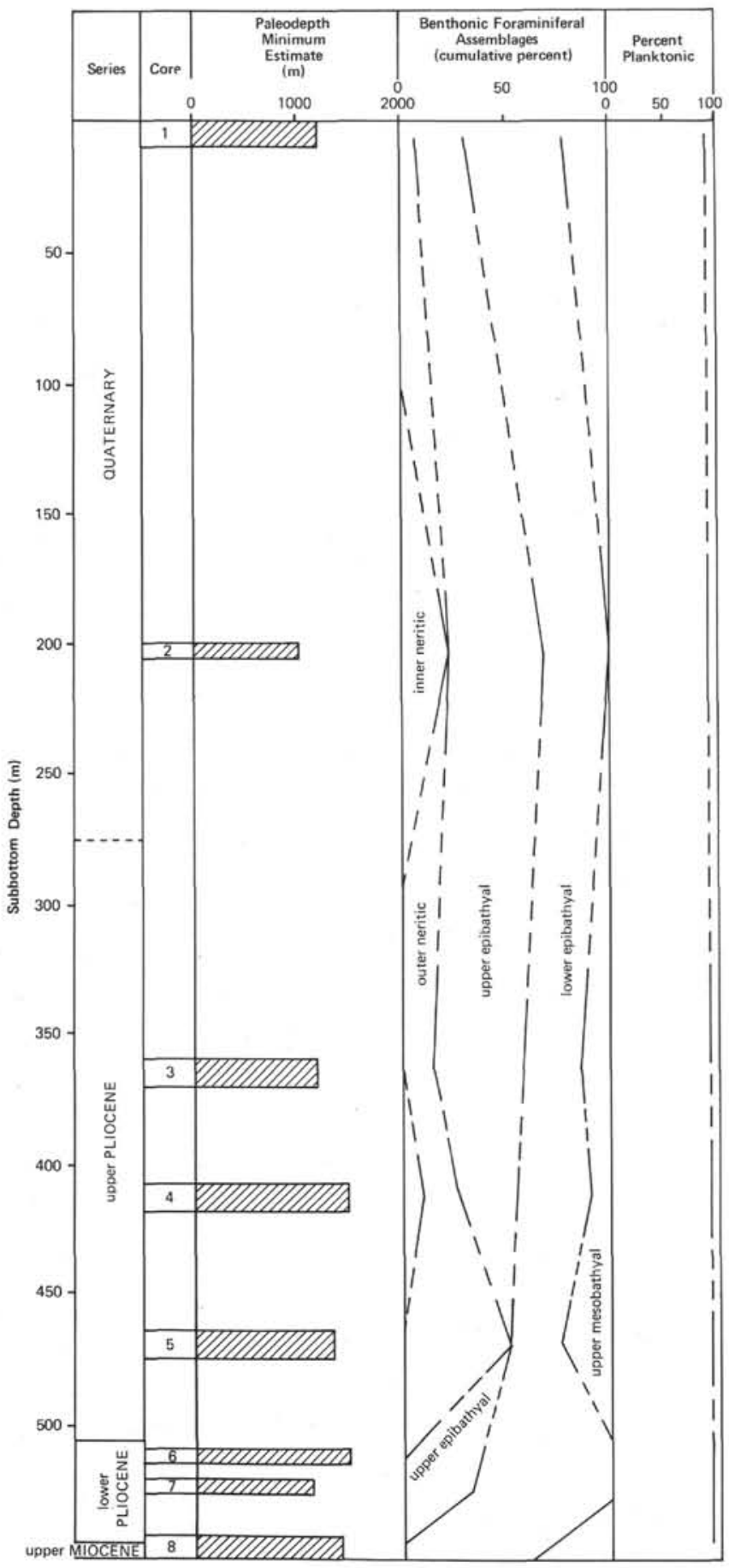

Figure 2. Paleobathymetric trends, Site 371, South Balearic Basin.

mesobathyal range. This "shallowing" may be a function of the gradual reintroduction of a deep water fauna into the basin after the late Miocene desiccation rather than a true change in basin configuration.

Sites 375 and 376 (Figures 5 and 6) in the Antalya Basin are complementary in that different portions of the Neogene sequence are exhibited at each location. The basin has been extant since the Burdigalian, although it appears not to have been as deep in the early and middle Miocene as during the Plio-Pleisto- cene (mesobathyal). The peculiar neritic faunas and shallow water environments that prevailed during the Messinian are discussed in detail in Cita et al. (this volume). The variable nature of the planktonic: benthic ratio in Site 376 in the Messinian sequence is due to the reworking of planktonic tests into a shallow water environment.

Site 377 on the Mediterranean Ridge yielded few samples with benthic foraminifers. The Pleistocene section contained a upper mesobathyal fauna. Only one Miocene sample contained benthic foraminifers. These poorly preserved specimens were conditionally placed in the mesobathyal zone.

Sites 378 and 378A (Figure 7) in the Cretan Basin show a Pleistocene basin not significantly different from that of today. However, the basin appears to have undergone subsidence during the Pliocene.

Whether or not a shallow sill existed between the eastern and western Mediterranean during the late Miocene and early Pliocene is not yet clear. The somewhat restricted benthic foraminiferal fauna found above the Messinian evaporites in the Messina Abyssal Plain (Site 374) can be explained in two ways. The fauna is dominated by Oridorsalis umbonatus, a species which is tolerant to a wide range of conditions and might be the initial inhabitant of a previously hostile environment. No physical barrier to migration is necessary in this model. If, however, a sill were present, $O$. umbonatus might easily be one of the first species to repopulate the Ionian area from the west since it is a lower epibathyal form that can survive at outer neritic depths.

The discovery that the pre-Messinian sediments even as old as the Burdigalian were deposited in bathyal depths in both the western Mediterranean (Site 372) and eastern Mediterranean (Site 375) lends support to the notion that a Mediterranean topographic basin has persisted over much of this area throughout most of the Neogene, and to the deep desiccation model for formation of the evaporites.

\section{ACKNOWLEDGMENTS}

The author wishes to thank DSDP for making it possible to visit several laboratories in Europe and to engage in enlightening discussions on the Recent foraminifers of the Mediterranean. Thanks also go to those who participated in these discussions: L. Blanc-Vernet, M. Cita, S. D'Onofrio, M. Moncharmont-Zei, R. Scorziello, and M. Zocchi. The critical reading of an early draft of this manuscript by $\mathrm{M}$. Cita, K. Hsü, J. Ingle, L. Montadert, and C. Pflum is greatly appreciated. Final review was by M. B. Cita, K. J. Hsü, and R. B. Kidd. This is Contribution No. 7 of the International Correlation Programme (I.G.C.P.) Project No. 96.

\section{REFERENCES}

Bandy, O. L., 1961. Distribution of foraminifera, Radiolaria and Diatoms in sediments of the Gulf of California: Micropaleontology, v. 7, p. 1-26.

Bandy, O. L. and Arnal, R. E., 1957. Distribution of Recent Foraminifera off the west coast of Central America: Am. Assoc. Petrol. Geol. Bull., v. 41, p. 2037-2053. 


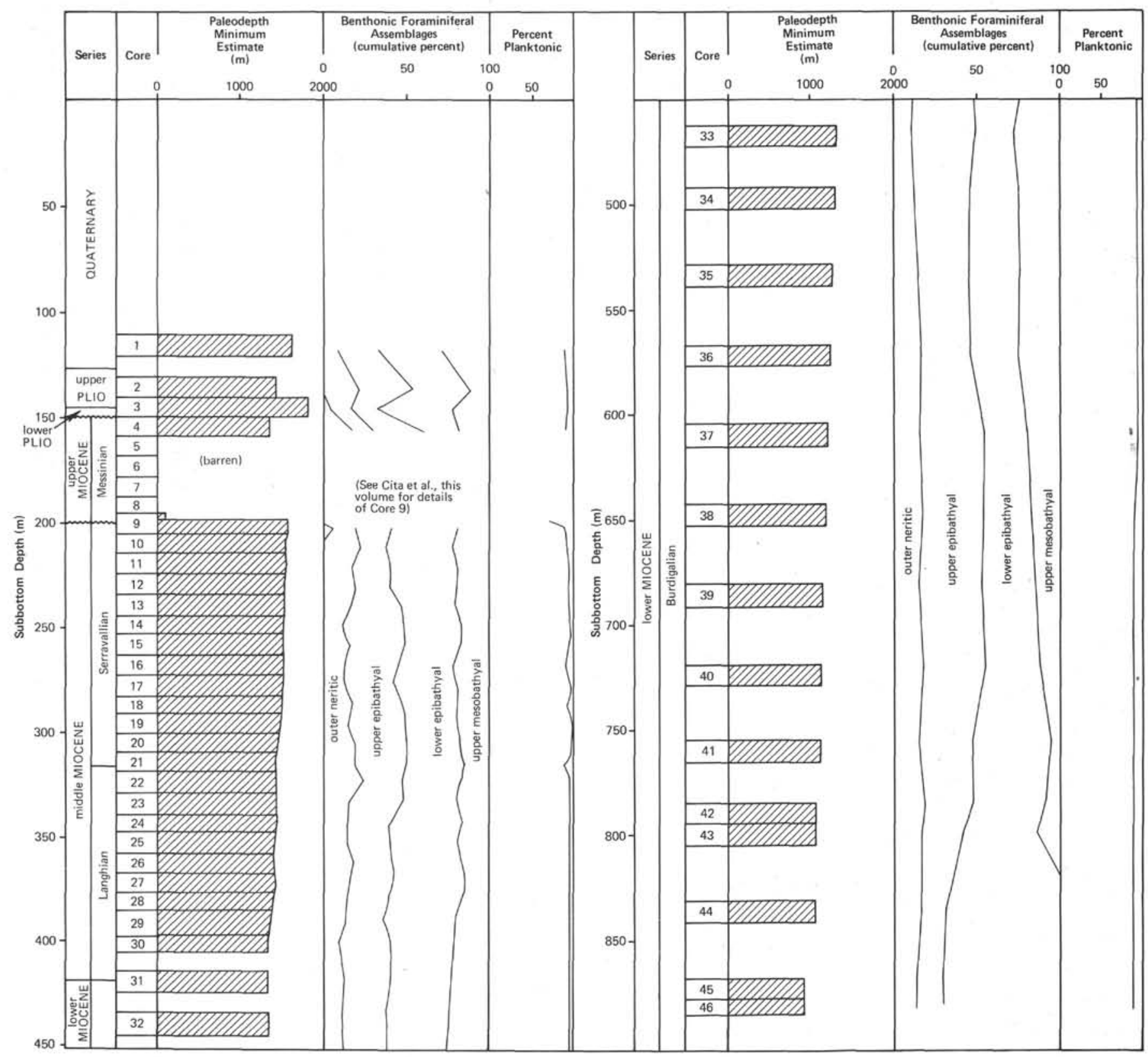

Figure 3. Paleobathymetric trends, Site 372, East Menorca Rise.

Bandy, O. L. and Chierici, M. A., 1966. Depth-temperature evaluation of selected California and Mediterranean bathyal Foraminifera: Mar. Geol., v. 4, p. 254-271.

Benson, R. H., 1973. Psychrospheric and continental Ostracoda from ancient sediments in the floor of the Mediterranean. In, Ryan, W. B. F., Hsü, K. J. et al., Initial Reports of the Deep Sea Drilling Project, Volume 13: Washington (U. S. Government Printing Office), p. 1002-1008.

Blanc-Vernet, L., 1969. Contribution a l'étude des Foraminifëres de Méditerranée: Extr. Recueil Trav. Stat. Mar. d'Endoume Bull. 64-48, p. 1-281.

Boltovskoy, E. and Wright, R., 1976. Recent Foraminifera: Dr. W. Junk, b.v., The Hague, 515 p.

Caralp, M., Lamy, A., and Pujos, M., 1970. Contribution a la connaissance de la distribution bathymétrique des Foraminifères dans le golfe de Gascone: Rev. Españ Micropaleontol., v. 2, p. 55-84.
Cita, M. B. and Zocchi, M., in press. Distribution patterns of benthic foraminifera on the floor of the Mediterranean Sea: Micropaleontol. Spec. Publ.

Colom, G., 1970. Estudio de los foraminíferos de muestras de fondo de la costa de Barcelona: Inv. Pesq., v. 34, p. 355384. 1-245.

1974. Foraminíferos ibericos: Inv. Pesq., v. 38, p.

Cushman, J. A., 1933. The foraminifera of the tropical Pacific collection of the "Albatross," 1899-1900: U. S. Nat. Mus. Bu 1. 161, p. 1-79. 1942. The foraminifera of the tropical Pacific collection of the "Albatross," 1899-1900: U. S. Nat. Mus. Bull. 161, p. 1-67.

Frerichs, W. E., 1970. Distribution and ecology of benthonic foraminifera in the sediments of the Andaman Sea: Cushman Found. Foram. Res. Contrib., v. 21, p. 123-147. 


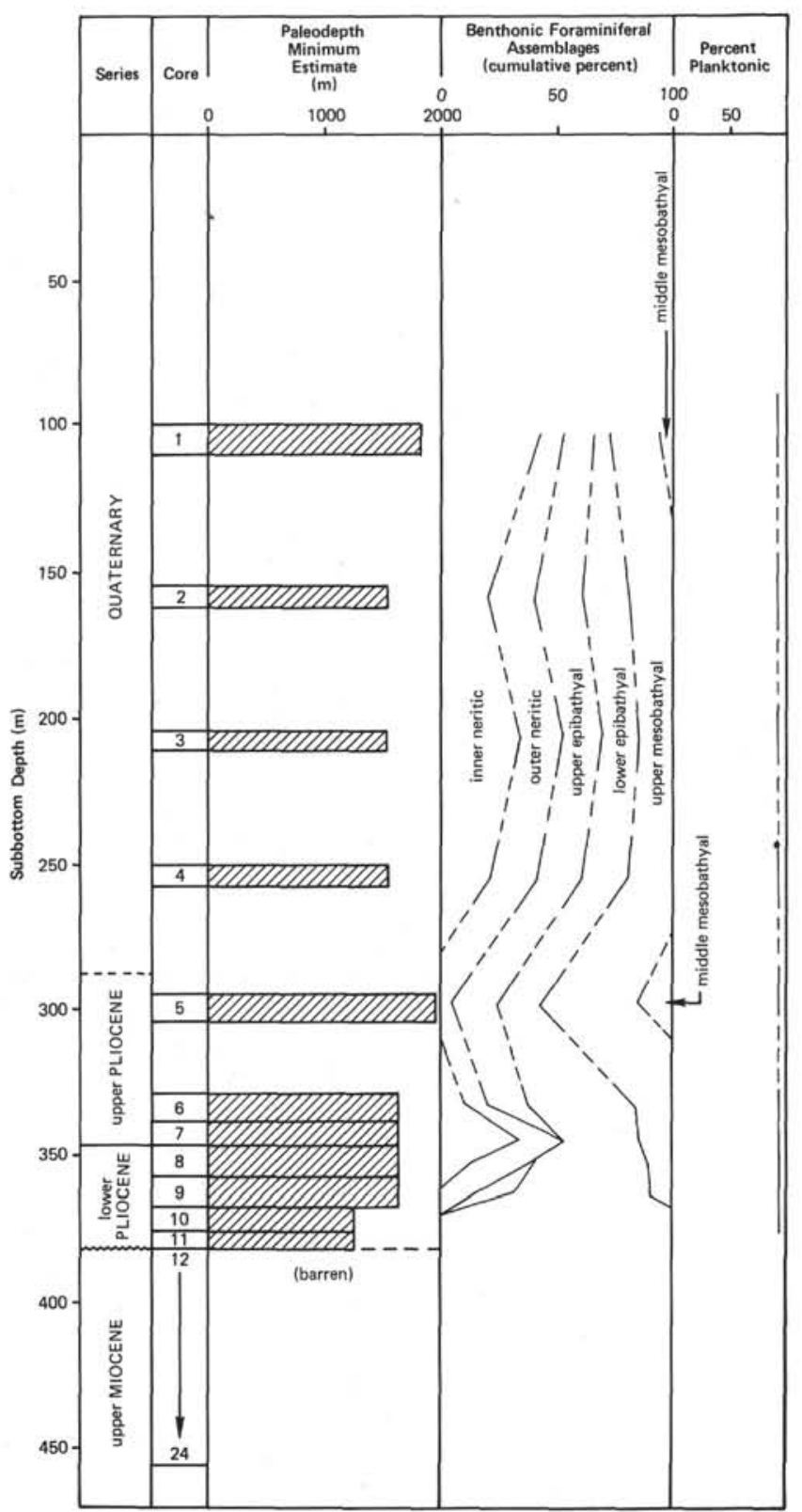

Figure 4. Paleobathymetric trends, Site 374, Messina Abyssal Plain.
Grimsdale, T. R. and Morkhoven, F. P. C. M., 1955. The ratio between pelagic and benthonic foraminifera as a means of estimating depth of deposition of sedimentary rocks: IV World Petrol. Congr., Proc., Sect. I/D., Rept. 4, p. 473-491.

Hedgepeth, J. W., 1957. Classification of marine environments: Geol. Soc. Am. Mem. 67, v. 1, p. 17.

Ingle, J. I., Jr., 1973. Neogene foraminifera from the Northeastern Pacific Ocean, Leg 18, Deep Sea Drilling Project. In Kulm, L. D., von Huene, R., et al., Initial Reports of the Deep Sea Drilling Project, Volume 18: Washington (U.S. Government Printing Office), p. 517-567.

Parker, F. L., 1954. Distribution of the foraminifera in the northeastern Gulf of Mexico: Harvard College Mus. Comp. Zool. Bull., v. 111, p. 453-588.

1958. Eastern Mediterranean foraminifera: Swedish Deep-Sea Exped. Rept., v. 8, p. 219-283.

Phleger, F. B. and Parker, F. L., 1951. Foraminifera species; In, Ecology of Foraminifera northwest Gulf of Mexico: Geol. Soc. Am. Mem. 46, p. 1-69.

Phleger, F. B., Parker, F. L., and Peirson, J. F., 1953. North Atlantic foraminifera: Swedish Deep-Sea Exped. Rept., v. 7, p. 1-122.

Pujos-Lamy, A., 1973. Repartition bathymetrique des Foraminifères benthiques profonds du Golfe de Gascogne. Comparison avec d'autres aires oceaniques: Rev. Españ Micropaleontol., v. 5, p. 213-234.

Ryan, W.B.F., Hsü, K. J., et al., 1973. Initial Reports of the Deep Sea Drilling Project, Volume 13: Washington (U.S. Government Printing Office).

Scorziello, R., 1966. Osservazioni sulla distribuzione batimetrica nel Golfo di Napoli di Amphicoryna scalaris (Batsch), Foraminifera: Estratto Publ, Staz. Zool. Napoli, v. 35, p. 115-129.

Theyer, F., 1971. Benthic foraminiferal trends, PacificAntarctic Basin: Deep-Sea Res., v. 18, p. 723-738.

Todd, R., 1958. Foraminifera from western Mediterranean deep-sea cores: Swedish Deep-Sea Exped. Rept., v. 8, p. 169-215.

1965. The foraminifera of the tropical Pacific collection of the "Albatross," 1899-1900: U.S. Nat. Mus. Bull. 161, p. 1-137.

Uchio, T., 1960. Ecology of living benthonic foraminifera from the San Diego area: Cushman Found. Foram. Res. Spec. Publ. 5, 72 p. 

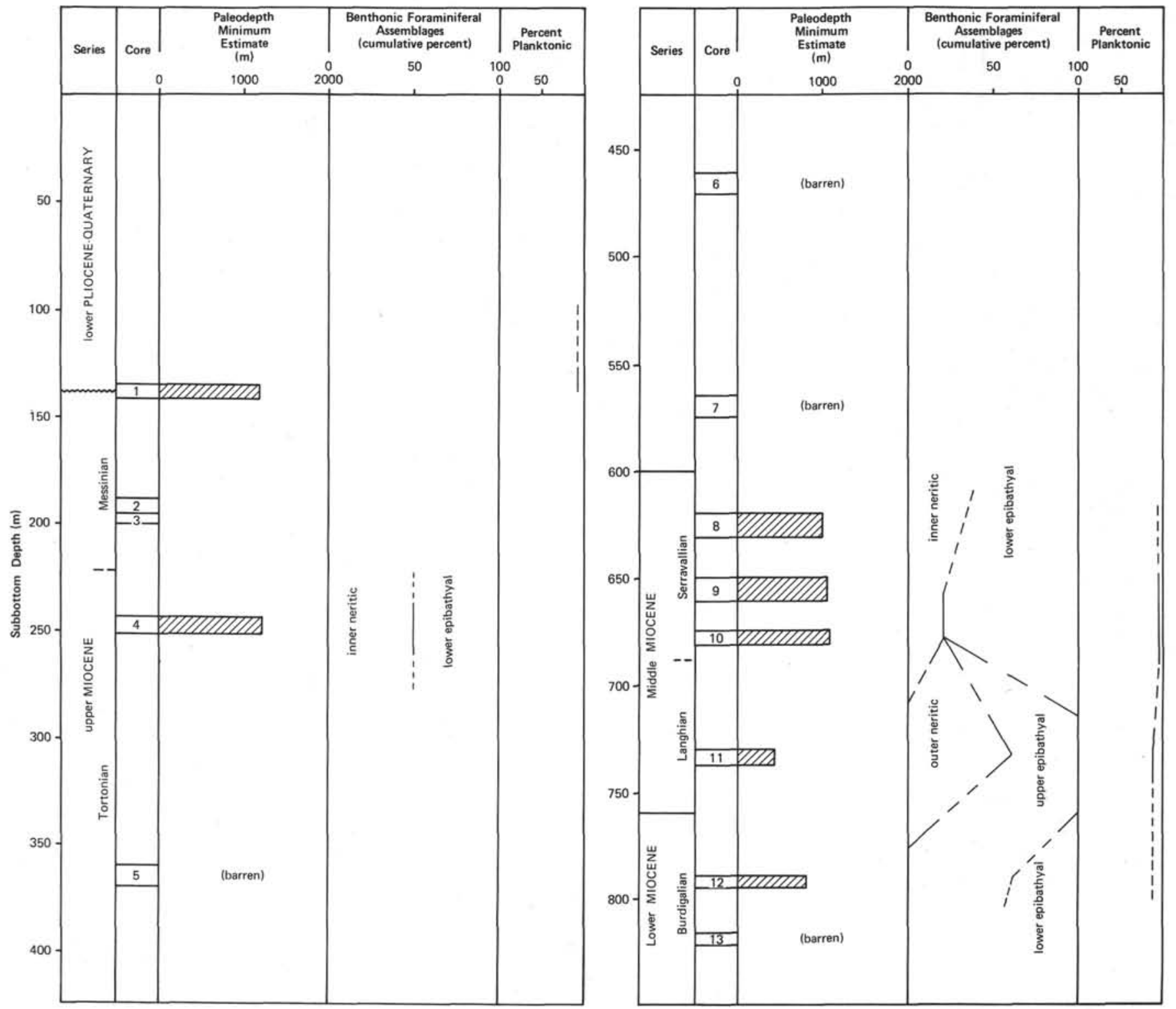

Figure 5. Paleobathymetric trends, Site 375, Antalya Basin. 


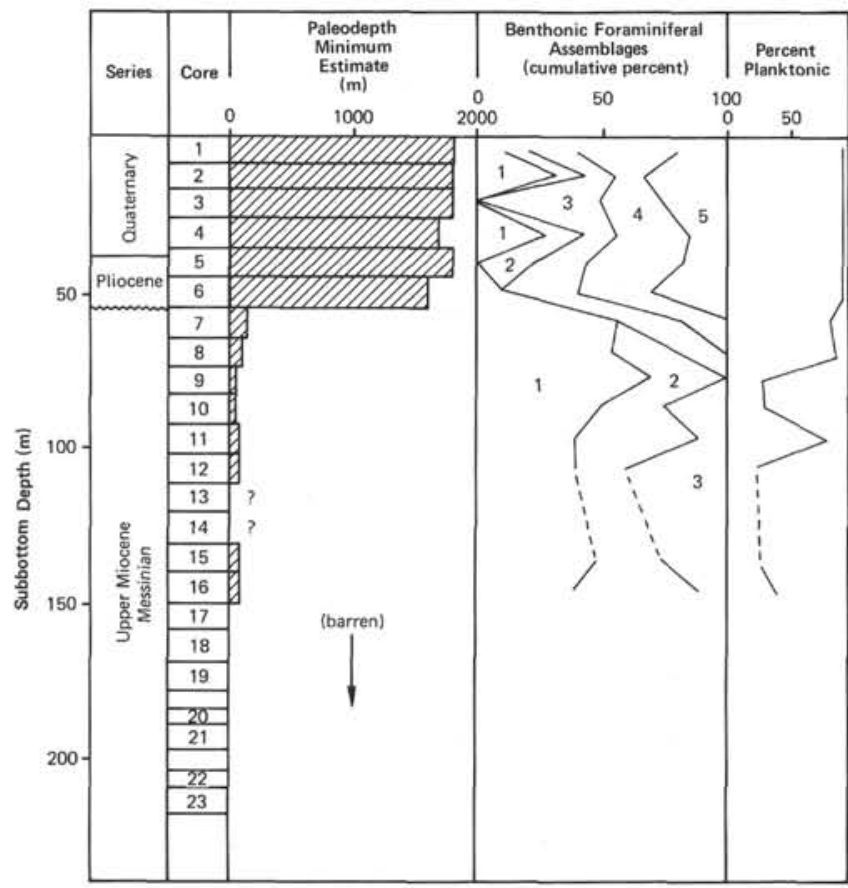

Figure 6. Paleobathymetric trends, Site 376, Antalya Basin. The benthic foraminiferal assemblages are: 1 - inner neritic; 2 - outer neritic; 3 - upper epibathyal; 4 - lower epibathyal; 5 - upper mesobathyal.

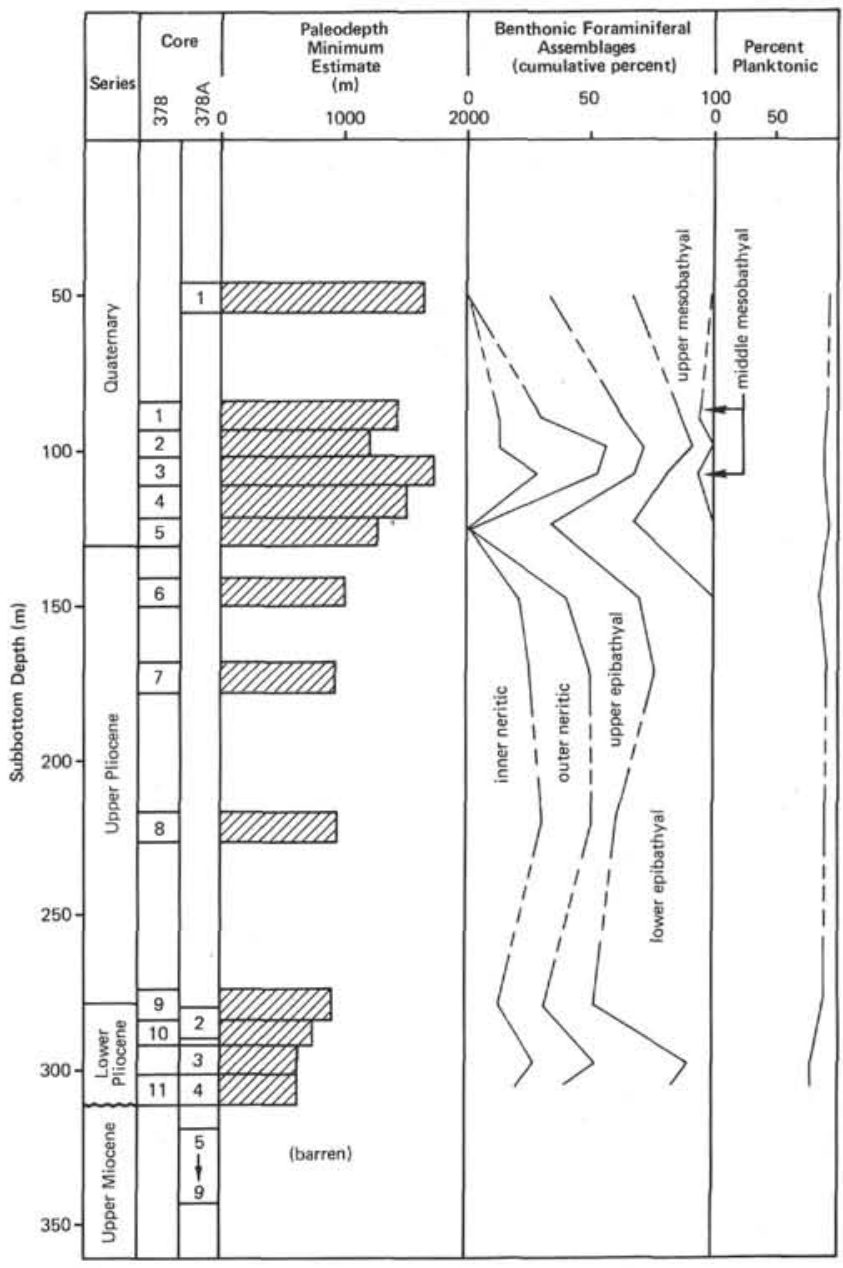

Figure 7. Paleobathymetric trends, Holes 378 and 378A, Cretan Basin. 